\title{
Tyra Kleen
}

Artist and spiritual seeker

$\mathrm{T}$

he Swedish artist and writer Tyra Kleen (1874-1951) was a professional artist and a constant traveller who had a great interest in different religious questions. This article describes her Symbolist artistry, her interest in Theosophy and her journeys to India and Asia.

\section{Introduction}

In Tyra Kleen's diaries, and in letters to the family from her years as an artist while in Paris and Rome, she describes how she participated in Spiritualist séances, attended lectures at Theosophical societies and visited exhibitions at the Salon de la Rose+Croix of Sar Péladan in Paris.

During her lifetime, Tyra Kleen was a respected and well-known artist, both in Sweden and abroad, and she exhibited her work in many cities and countries around the world. But, like many artists of the twentieth century, she was forgotten after her death. In her will she donated her estate to the Swedish nobility, including her house at Lidingö in Stockholm, with the request that all her material - her work, sketches and letters etc., should be kept hidden for 50 years after her death. She died in 1951, therefore in 2001 her material was brought out of its concealment. Her artistry is now being rediscovered.

Knowing that Tyra Kleen was a spiritual person with a great interest in esoteric issues can give us a new dimension to her work. Her oeuvre is more than just beautiful and interesting. Looking at it from an esoteric perspective - trying to trace symbols or signs of her religious beliefs - may give us a sense of a new and somewhat deeper dimension to her work. This article is an attempt to add an esoteric perspective to the life and artistry of Tyra Kleen.

\section{Background}

Tyra Kleen was born in Sweden in 1874 but lived abroad for many years of her life. Her family was a part of the Swedish nobility and belonged to the cultural elite of the time. She was the youngest of three siblings and while she was growing up she went to the opera, concerts, theatres, formal receptions, dinner parties, even attending the Nobel Prize festivities. Since Tyra Kleen's father worked within the Swedish diplomatic field, the family travelled a lot and therefore she learned several languages and made friends in many countries. She was an independent person and saw herself as a European artist and a vagabond rather than just a Swedish artist.

Tyra Kleen was sent abroad for her artistic education, firstly to schools for girls in Germany. After that she went to Paris together with her mother for art education, 
and later on she went to Rome on her own. During her life she travelled a lot; she went by boat or train to India, Ceylon (Sri Lanka), Java, Bali, the West Indies, North Africa, the US and to many cities in Europe. Due to her international education and to her travels Tyra Kleen acquired a unique artistic and continental Symbolist style such as we do not find with other Swedish artists. She also had a remarkably wide network of international artists and friends.

\section{Art education in Germany}

Like many young women of the upper classes in Sweden at the time, Tyra Kleen was educated as a young girl at home by a governess. In 1890, at the age of 16 , she was sent abroad to a school for young girls in Dresden, Germany. Subsequently she spent a few years attending art schools for young girls, first in the Malerinnen Schule in Karlsruhe, and later on in Munich in 1894. During these years she was trained in the Art Nouveau/Jugend style and she was inspired by the symbolist artists Arnold Böcklin and Max Klinger. In her somewhat incoherent notes in her diaries from these years she describes her classes and lectures and how her teachers were pleased with her work. She also describes many visits to art museums and galleries to study art, and she lists her favourite works of art: "̈̈lsklingstaflor bland de moderna' ('My favourite modern works of art', Diaries of Tyra Kleen, 1890-5).

\section{Symbolism in Paris 1895-8}

Paris at the turn of the nineteenth century was a very dynamic and busy city. The French capital was at the centre of attention, a melting pot, where 'all the action' was taking place. Many people of different backgrounds and nationalities gathered in Paris where the art movement called Symbolism manifested itself in the late 1880 s. Sym- bolism attracted intellectuals, writers, poets and artists. Among many Symbolist notions was that of looking beyond the physical world. Symbolist literature's great precursor, the poet Charles Baudelaire, put forward theories of 'correspondences' - meaning, for example, that a line or a colour would evoke a mood or experience - which became important directives for the artists. A Symbolist artist should not merely depict real life as it appeared; rather, the subjects should be dreams, nightmares, fantasies and fairy tales. The idea behind the subject of an image was however not perceptible to everyone. Only those who had the knowledge of some esoteric secrets could understand the true meaning of the works. The hidden meaning was only for a few, the consecrated, in accordance with the esoteric ideals (Greene 2017: 16).

In 1895 Tyra Kleen and her mother went to Paris where they stayed until 1898. Tyra Kleen attended several of the private art schools in Paris, namely the Académie Julien, Académie Delecleuse, Académie Colarossi and Académie Vitti and also the French Académie de Beaux-Arts. She worked hard and was very productive; she attended classes at art schools and visited museums and art galleries during the days, whilst in the evenings she visited lectures, seminars and séances - so that she met and made the acquaintance of many people and became part of a wide network. She applied for, and was granted, permits to copy art works at museums and spent many hours drawing and copying items at the Gallery Luxembourg and the Louvre. She made a perfect copy of the iconic symbolist work, Le Pauvre Pêcheur by Pierre Puvis de Chavannes, in 1881 while copying at the Gallery Luxembourg. ${ }^{1}$

1 Notes from diaries, March and April 1897, more information in Ström Lehander 2018. 


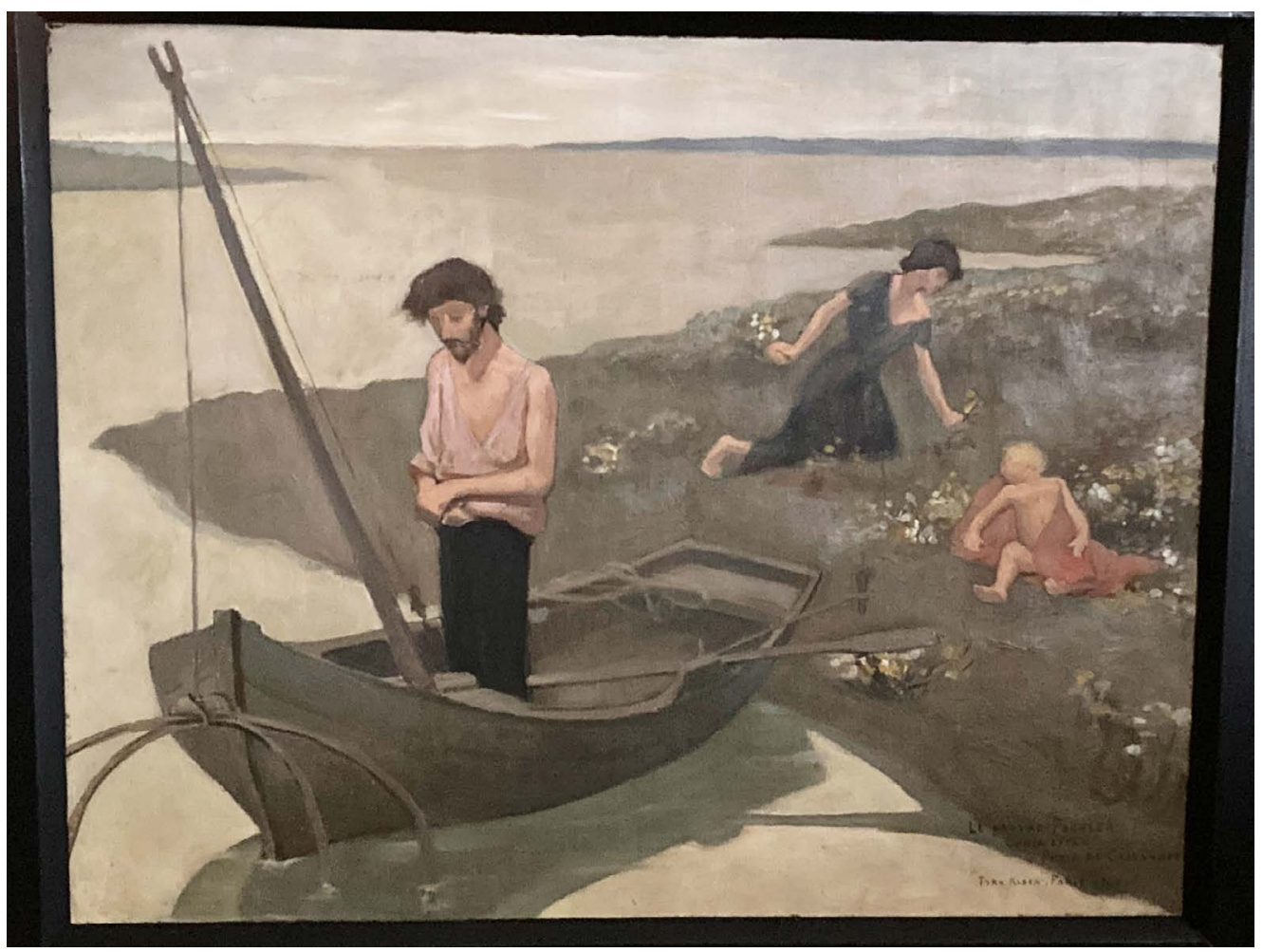

Tyra Kleen's copy of Pierre Puvis de Chavannes's Le Pauvre Pêcheur, 1896, oil painting. Tyra Kleen collection, Riddarhuset/Valinge gård. Photo: K. Hermelin.

Whilst she was in Paris Tyra Kleen visited the L'Ordre du Temple de la Rose+Croix society, amongst others, whose influential leader Sar Péladan (JosephAimé Peladan 1859-1918) arranged art exhibitions in between 1892-7. The society was very influential and played an important role in the field of art and in the artistic life of Paris generally, as Symbolist art was shown and lectures on Symbolism and art were held at its salons. From the diaries of Tyra Kleen we learn that she attended lectures and participated in gatherings and visited art exhibitions. Several influential artists were invited to show their works

Tyra Kleen's version of the Pouvre pêcher was showed at the exhibition Symbolism \& dekadens at the Waldemarsudde museum, Stockholm 2015-16. there. Nota bene: only male artists were invited to exhibit their works at the Salon de la Rose+Croix. No women artists were invited to exhibit their works. The society had a hostile attitude towards women artists and therefore women were forbidden to work artistically or to have any active role in the Rose+Croix society, according to a 'magical law' of its leader Sar Péladan. According to the directives of Sar Péladan, art works for the salons should be mystical, idealist and in the service of beauty. Subjects such as historical scenes, still lifes, domestic scenes, animals, and landscapes were excluded from the Salon of Rose+Croix, in accordance with the rules of Péladan (Greene 2017: 16; Cornell 1981: 150; Facos 2009: 174).

From letters and notes in her diary we understand that Tyra Kleen was frustrated 
over the negative views about and hostility towards women artists that she experienced at the Rose+Croix and she felt excluded as an artist. Tyra Kleen praises most of the Symbolistic work that the different artists show at the salons, but claims that Sar Péladan himself is totally without artistic skill. In 1898, after having spent three years in the French capital, Tyra Kleen and her mother left Paris and moved back home to Sweden.

\section{Theosophy in Rome 1898}

Back in Stockholm again in 1898, Tyra Kleen was refused attendance at courses at Kungliga Konstakademien, the Royal Academy of Art. She decided instead to leave Sweden and move to Rome, where she would stay and work for almost ten years, with short breaks. The time in Rome was a very productive and creative period in her artistry. In Rome she had her own atelier, where lithography was her favourite medium. She was active and attended exhibitions at which she showed her work. She was also engaged in, and a participant of, the Theosophical Society in Rome, where she became a member in 1904. Tyra Kleen was also involved in the Scandinavian Society in Rome, where she even was a board member for some time.

Like many writers and artists at the time, Tyra Kleen had a great interest in Theosophical theories and ideals. Being a strong and independent person, Theosophical ideas accorded with Tyra Kleen's artistic identity. She was the first professional woman artist in her family, and she did not want to give up her artistry; nor did she want to lose her freedom, which is probably why she did not marry, even though she had several proposals. The artist was inspired by - and good friends with - the author and educationalist Ellen Key (1849-1926) whose ideas concerning women's rights were quite controversial at the time. The friendship with Ellen Key clearly encouraged Tyra Kleen to live an artistic and independent life on her own.

The subjects in Tyra Kleen's images were well composed and aesthetically coherent, but the images also had a deeper meaning, not for everyone to understand. To be able to comprehend the underlying message of the subjects, one would have to know the esoteric or Theosophical meaning of the symbols presented. For example, the image Sed non Satiati, shows a man and woman kissing each other. They are both naked on a terrace by a small pool; the man is lying on his stomach and the woman on her back, they are united in a kiss. The two bodies are at the centre of the image; behind their heads the sun is setting, or maybe rising, with a beautiful sky, scattered clouds and a city skyline as a backdrop. The woman's hair flows down into the water. The title Sed non Satiati is a direct reference to Charles Baudelaire's poem 'Sed non satiata', Latin for 'She is not yet satisfied', the poem portraying a woman as a vampire thirsty for blood. But Tyra Kleen changes the title and hence the meaning of the image: now showing the united couple as an image of human androgyny instead, and as an association of opposites, with references to Plato and Theosophy. The woman is no longer a demon and vampire, but the one half of a whole. The theory of androgyny is central in Theosophy, as is the idea of a united whole combining both female and male characteristics (Steorn 2010: 182; Faxneld 2020: 41).

Tyra Kleen worked in several artistic media; from oil painting and watercolour to drawing and lithography. She also wrote articles and books and worked as an illustrator. She tried her hand at sculpting and took a sculpture class in Paris, but decided she was not strong enough for the 


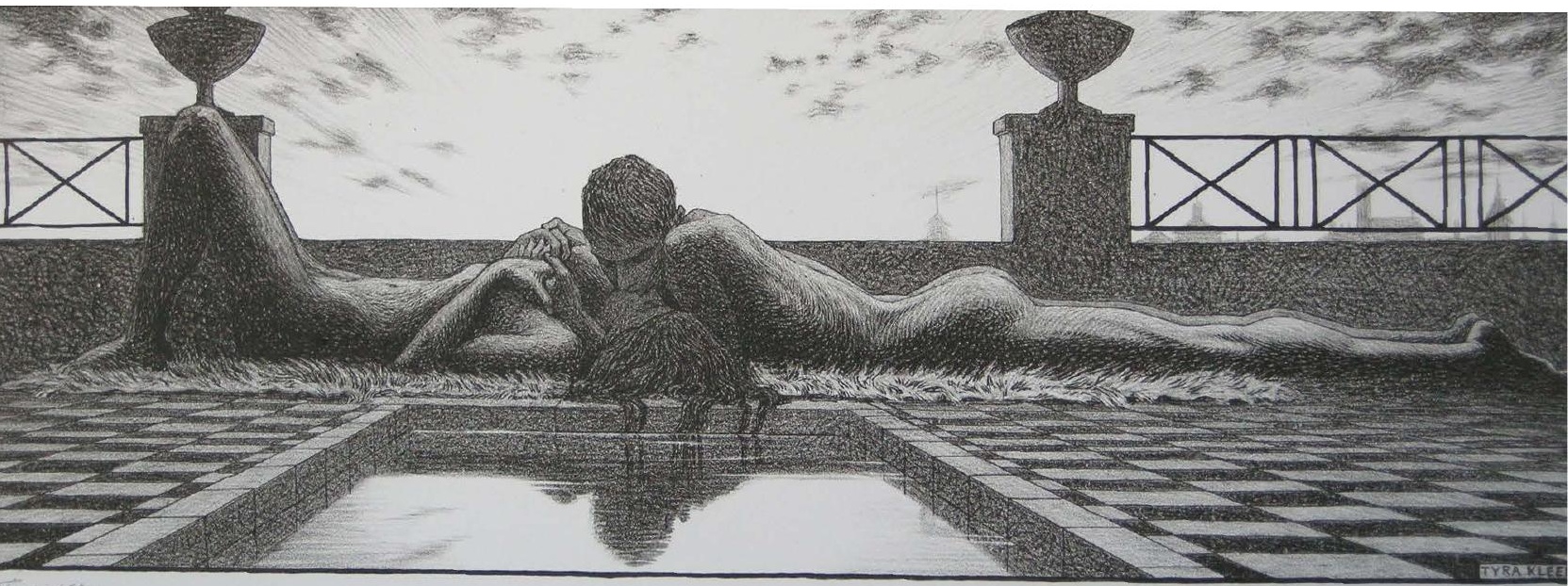

SED NON SATIATI

Tyra Kleen, Sed non Satiati, 1902, lithography. Tyra Kleen collection, Riddarhuset/Valinge gård. Photo: G. Pravitz.

demanding and heavy work the discipline required.

\section{Working in Stockholm from 1907}

Tyra Kleen moved back to Sweden in $1907 / 8$ and was active in designing and building a house for herself at Lidingö in Stockholm. In the house there was a large atelier with windows in the ceiling/roof top to allow a good and steady supply of light, and podiums for models to stand on. The artist enjoyed sunbathing, a habit picked up during her time in Rome, and designed a large balcony on the roof of her house for this purpose.

In 1908, the artist wrote a book, Form, in which she explains her ideas and theories of beauty. She argues that the perfect shape is the absence of unnecessary decoration, which statements she attributes to 'Michael Angelo' and 'Emerson'. Tyra Kleen describes how an artist creates objects of beauty by choosing the adequate form for the idea of the subject. In an interview in 1909 in the magazine Idun, Tyra Kleen explained how she worked; in her drawings the ground-laying foundation was to depict the idea behind the subject, in accordance with the Symbolist art style. She would depict the subject by drawing lines. Colours were not as important to her, nor was the form or the shape of the artwork as important as the idea behind the subject of said artwork (Wägner 1909: 93-7; Kleen 1908: 23, 28, 55-7).

While in Stockholm Tyra Kleen was active in the process of founding a society for women artists in Sweden. She had been one of the founders of a society for women artists in Rome in 1900 and experienced the need for the same type of society in Sweden too. Föreningen Kvinnliga Konstnärinnor had its first exhibition at the Royal Academy of Art, in 1911 where Tyra Kleen exhibited her work.

One of the many Spiritualist societies in existence around 1900 was the Edelweiss Foundation, founded in 1890 by Mrs Huldine Beamish-Mossander (1836-92). After her death, the daughter Huldine Fock 


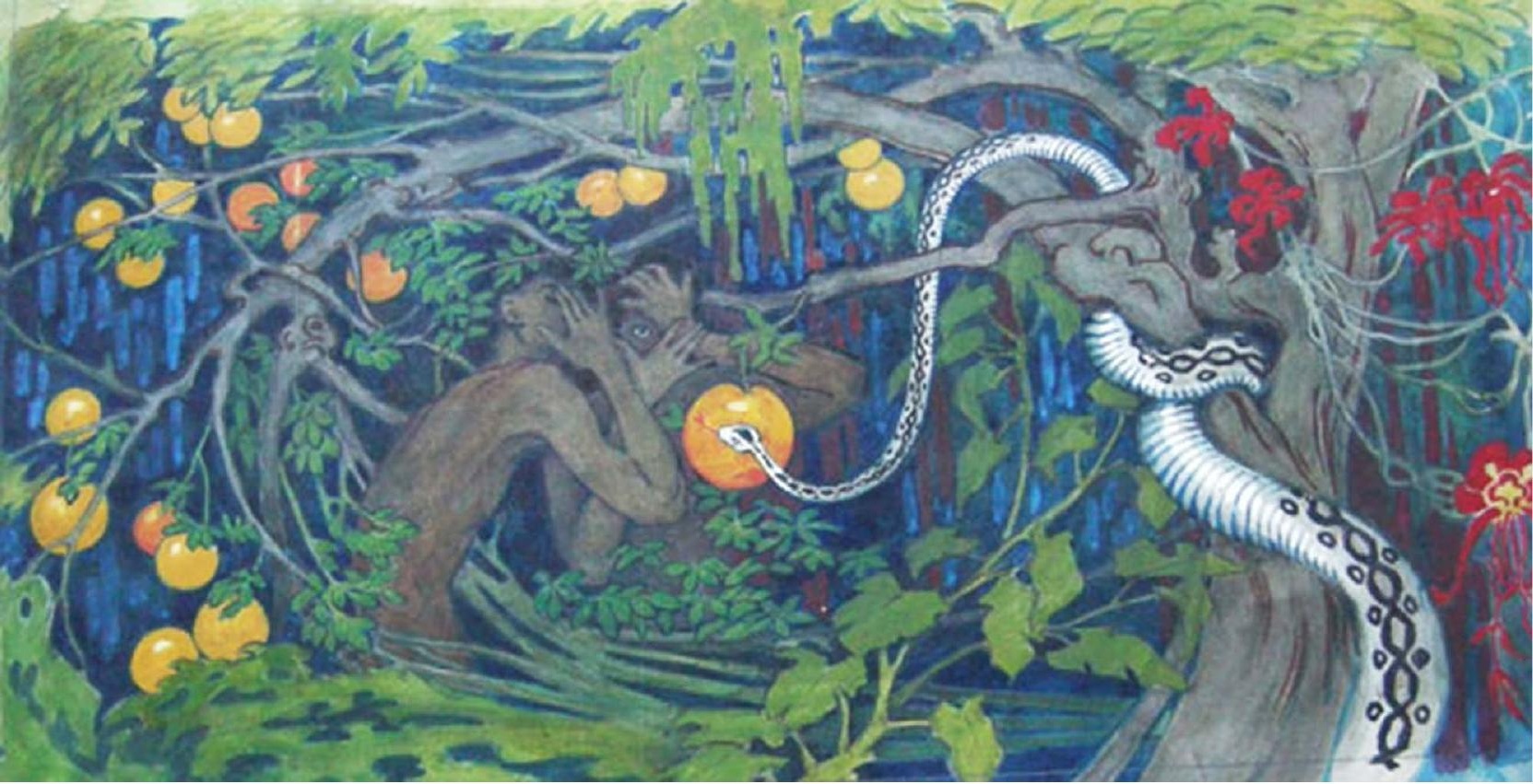

Tyra Kleen, Förbjuden frukt (Forbidden Fruit), 1915, gouache. Tyra Kleen collection, Riddarhuset/ Valinge gård. Photo: Bobo Lindblad.

(1688-1772) claimed that he also was able to predict his own death. So here we find yet another, the very last, sign of the occult and esoteric side to the artist Tyra Kleen.

\section{To India in 1911}

Tyra Kleen enjoyed travelling, and on 1 January 1911, she and her good friend Ellen von Platen left Europe from Naples for a long journey by boat. The artist describes the voyage in the book Strövtåg $i$ Orienten (Forays in the Orient) in 1911. During the trip, which lasted for three months, Tyra Kleen visited the town of Adyar, where the Theosophical Society had moved its headquarters after the split following Madame Blavatsky's death in 1891. In her book Tyra Kleen advocates living one's life close to nature, giving the example of the famous Theosophical couple Prince Ruspoli and his English wife, both formerly very active in high society life in Rome, but after moving to India living very happily in silence and isolation in the headquarters in Adyar (Kleen 1911: 67). Here, we can trace the Theosophical ideas of the ideal life of primitive societies living peacefully and calmly in a symbiosis with nature, in Tyra Kleen's argumentation (Facos 2009: 30).

During the trip to India Tyra Kleen questioned why the Europeans impose Christianity on the native people when they seemed already to be fully content living the way they did. The artist gives an example in Strövtåg $i$ Orienten of how she met an English woman, a missionary, on a train in India, who was on her way back to Great Britain. The woman had completed her work, her mission, and was now going back home. She was quite disappointed since during her time as a missionary she had only been able to convert one single person, a young girl, to Christianity. And this young girl did not dare to tell her father she had become a Christian. Tyra Kleen thought the missionary to be quite ignorant for not understanding the girl's dilemma. The young girl could not tell her father she had become Christian, as he would kill her. Let everyone keep their own religions and traditions, was Tyra Kleen's own belief (Kleen 1911: 113). 
Why can we not let the Hindus keep their concerns to themselves. Just as they do not interfere with ours. Why do the white people wish to crowd in the same hell as the natives, when they usually are quite keen on separating all localities. They have separate hotels and railway coaches, separate waiting halls and restaurants - everywhere there is a sign saying 'for Europeans' or 'for natives'. (Kleen 1911: 113-14)2

The artist was clearly fascinated by the culture and traditions of India. For example, she describes in detail the practice and the arrangements regarding the tradition of burning the bodies of the newly deceased in Strövtåg $i$ Orienten. However, she is strongly against the tradition of burning the widow of a deceased man (Kleen 1911: 157-60).

Tyra Kleen made the gouache Förbjuden frukt (Forbidden Fruit) in 1915, four years after her trip to India and Ceylon. While drawing this green paradise, she was clearly inspired by the jungles she had visited and experienced during her trip. In a Christian context a snake normally has a negative connotation, as the traitor of the Garden of Eden, but with the aid of a reading from the Theosophist Helena Blavatsky (183191) you can see the snake as something positive, as a bearer of light and salvation. Knowing Tyra Kleen was a Theosophist and well versed in these ideas, this reading

2 Swedish original: Varför kunna inte hinduerna få ha sina angelägenheter ifred. Liksom de låta européerna ha sina? Varför vilja de vita just trängas med infödingarna i samma helvete, när de eljes äro så angelägna att ha alla lokaliteter åtskils? De ha skilda hotell och järnvägskupéer, skilda väntsalar och restauranger - överallt sitter en skylt, där det står antingen 'For europeans' eller 'For natives'. could have been the meaning of the work Förbjuden frukt (Faxneld 2020: 71).

\section{By boat to Java and Bali in 1919}

After the end of World War I, on 6 October 1919, Tyra Kleen embarked on a voyage with the steamship 'Bullaren' to Java and Bali. It was a long journey; it took a month to reach Batavia, the capital of the former Dutch East Indies, and she was seasick due to stormy weather. In Batavia she visited the Theosophical Society and arranged to have an art exhibition. She travelled around the islands, visited temples and palaces and ended up staying for two years in Java and Bali, until 19 October 1921. She sketched and painted dancers at the temples and captured the hand movements

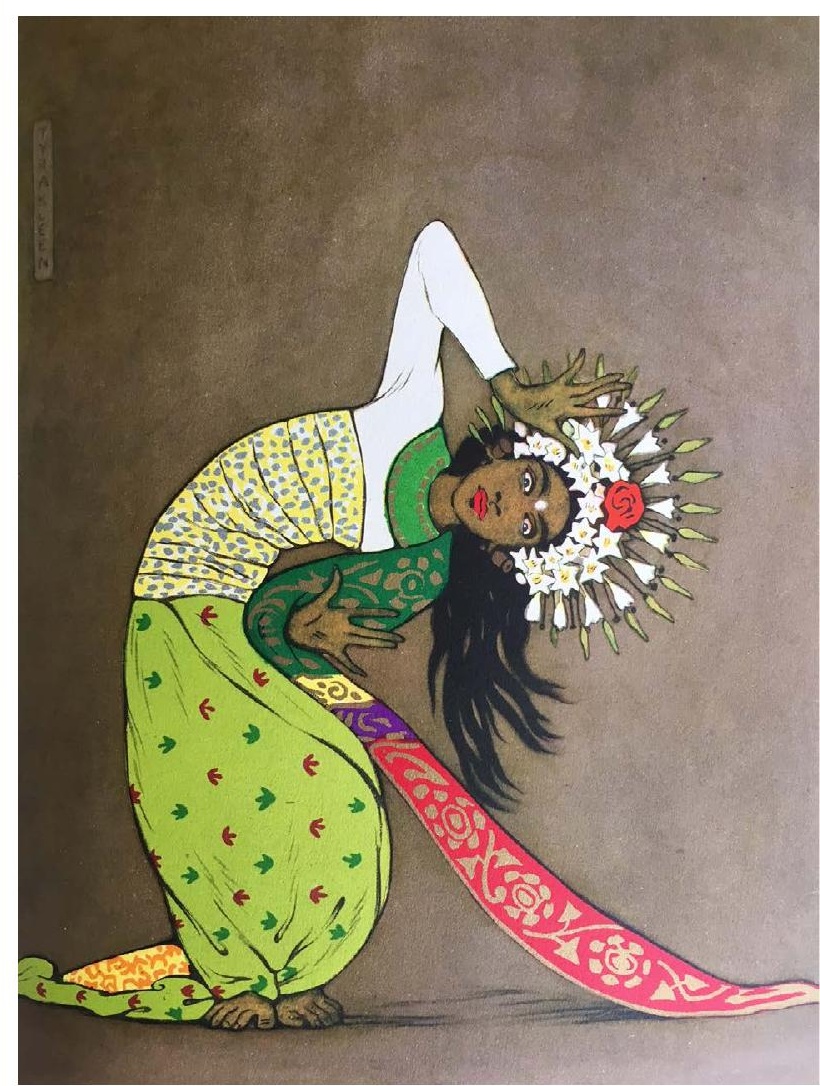

Tyra Kleen, Temple Dancer from Java/Bali, 1920, print from original gouache. Tyra Kleen collection, Riddarhuset/Valinge gård. Photo: Riddarhuset. 
of the priests, the so-called mudras, during her stay. She produced many sketches, drawings and watercolour paintings and gathered a lot of material such as scarves, fans, and knives, which she brought home. Back in Europe again she wrote books on the theme of temple dancers and mudras in Java and Bali. She created art exhibitions of the material and the artwork produced during the trip and showed her art at exhibitions in Stockholm and The Hague in the fall of 1922, and at the Royal Geographical Society and at the Victoria \& Albert Museum in London in the spring of 1923. She also wrote a book for children in Sweden, about how children lived in Java and Bali (Kleen 1924).

Being a woman, the artist was given access to temples and royal courts where male artists could not get in, as men were forbidden to enter. Tyra Kleen drew the hand movements of the priests and the temple dancers in colourful dresses. She depicted some of the dancers with decorative shading and smoke rings in stylised patterns, clearly in the style of Jugend/Art Nouveau. Applying an esoteric interpretation however, the lines around the figures could be interpreted as more than just decoration; rather as depictions of the auras around the person of the portrait.

\section{Conclusion}

The artistry of Tyra Kleen is being rediscovered. More research is now being carried out into the material she left behind. We can certainly observe similarities between her work and other Symbolist artists. However, Tyra Kleen took it one step further and, making some very unique responses to Symbolist writers and poets, turned these into interesting images. She seems to have been a constant traveller and a constant seeker, very much like other Symbolist artists of the time. The notion of the typical 'seeking artist', as exemplified by Nina Kokkinen , could well be applied to the artistry and life of Tyra Kleen (see Kokkinen in this issue).

Tyra Kleen was a talented artist, but she was also an author of books and articles. She illustrated her own texts and books, as well as the works of other writers. Since she was multi-talented and produced a varied oeuvre, she is somewhat difficult to understand, analyse and pin down. Furthermore, her engagement in depicting the Java and Bali dances and traditions and the prize she was awarded for her ethnographical work in 1920, made her even more difficult to categorise. This could be one reason to why she is not included in the artistic canon of the time, as Patrik Steorn has pointed out (2010: 184).

Many of her symbolist subjects from Rome, and the dancers and mudras from her travels, have been exhibited in recent years, since the collection was brought out of its concealment in 2001. Around thirty of her images were shown at the exhibition Måleri och andlighet - Hilma af Klint, Tyra Kleen och Lucie Lagerbielke ('Art and Spirituality: Hilma af Klint, Tyra Kleen and Lucie Lagerbielke') at the Millesgården museum in Stockholm, September 2019 February 2020, and more exhibitions will follow.

\section{Karin Ström Lehander} is a PhD student in art history at Åbo Akademi University, researching 'Tyra Kleen: woman, artist and cosmopolitan'. Ström Lehander has an MA in art history from Uppsala University and

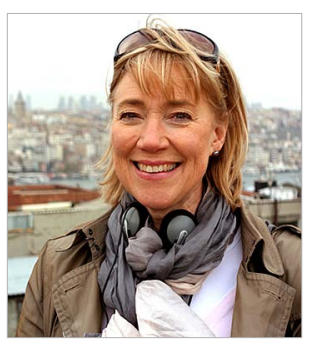
works as a university adjunct, teaching art history and visual communication at Linköping University, Sweden. Ström Lehander has been examining the material of the artist Tyra Kleen since 2013, writing several chapters in anthologies 
and literature and has curated an exhibition Två konstnärskap $i$ vår tids ljus ('The Oeuvres of Two Artists in Our Time') at Östergötland's Museum in Linköping 2016.

\section{References}

\section{Tyra Kleen's literary production}

Kleen, Tyra [by pseudonym 'Isis']. 1900. Lek. Från Roms bohême-värld (Stockholm: Bokförlaget Bonnier).

- -1902. En psykesaga (Stockholm: Wahlström \& Widstrand).

- -1908. Form (Stockholm: Sandbergs bokhandel, Nya Tryckeri-aktiebolaget).

- - 1910. 'Symbolism för alla', Aftonbladet, 24.9.1910.

——1911. Strövtåg i Orienten (Stockholm: P.A. Norstedt \& Söners Förlag).

-_1924. Mudras: The Ritual Hand-poses of the Buddha Priests and the Shiva Priests of Bali (London: Trench, Trubner \& Co).

- -1924. Ni-Si-Pleng. En historia om svarta barn berättad och ritad för vita barn (Uppsala: Lindblad).

- -1930. Vajang. Javajansk teater (Stockholm: Rotogravyr).

- - 1931. Tempeldanser och musikinstrument på Bali (Stockholm: Rotogravyr).

- - 1936. The Temple Dances in Bali, Statens Etnografiska Museum, New Series (Stockholm: Statens Etnografiska Museum).

-_1937. Wayang: Javanese Theatre, Statens Etnografiska Museum, New Series (Stockholm: Statens Etnografiska Museum).

-_1946. Solens son (Stockholm: Gothia).

\section{Unpublished references}

Interview with Kerstin Hermelin, trustee of the Tyra Kleen estate, Valinge, November 2019.

Tyra Kleen's diaries 1887-1905, 1907-9. Riddarhuset, Valinge gård (deposition), Nyköping, Sweden.

\section{Literature}

Cornell, Peter. 1981. Den hemliga källan. Om initiationsmönster i konst, litteratur och politik (Stockholm: Gidlunds).

Facos, Michelle. 2009. Symbolist Art in Context (Berkeley, Los Angeles, London: University of California Press).

Faxneld, Per. 2020. Det ockulta sekelskiftet.
Esoteriska strömningar i Hilma af Klints tid (Stockholm: Volante förlag).

Greene, Vivien. 2017. 'The Salon de la Rose+ Cross: the religion of art', in Mystical Symbolism: Le Salon de la Rose+Cross in Paris 1892-1897 (New York: Guggenheim), 16.

Sidén, Karin. 2016. 'De ihågkomna och de bortglömda', in Ljusets magi. Friluftsmåleri från sent 1800-tal, utställningskatalog Waldemarsudde 118:16, eds. Karin Sidén och Anna Meister (Stockholm: Waldemarsudde), 60-107.

Steorn, Patrik. 2010. 'Bilden som ett arkiv över dold mening, Konst och andlighet hos Tyra Kleen', in Det åskådliga och det bottenlösa. Tankar kring konst och humaniora tillägnade Margaretha Rossholm Lagerlöf, eds. Tomas Björk et al., Eidos, 22 (Stockholm: Skrifter från Konstvetenskapliga institutionen vid Stockholms universitet), 178-84.

Ström Lehander, Karin. 2018. I Tyra Kleens fotspår. En studie över konstnärens tid i Rom och Paris 1892-1908, master's thesis in art history, Uppsala university, <http://urn.kb.se/ resolve?urn=urn:nbn:se:uu:diva-355263>.

Wägner, Elin. 1909. 'Linjer och symboler. Några ord om Tyra Kleen och hennes konst', Idun: Illustrerad tidning för kvinnan och hemmet (Stockholm), 93-7. 